\title{
An Important Problem in Physician-Patient Relationship: Burnout and Factors Affecing Burnout in Family Physicians
}

\author{
Hekim-Hasta İlişkisinde Önemli Bir Sorun: Tükenmişlik ve Aile Hekimlerinde Tükenmişliği Etkileyen \\ Faktörler
}

\author{
Mustafa SAMANCI ${ }^{1}$, Elif DIKKMETAȘ YARDAN ${ }^{2}$
}

\begin{abstract}
The study aimed to determine the burnout levels of physicians, which is an important factor in the physician-patient relationship, and the factors affecting this level. The study was applied in family health centers in Samsun between 21.03.2018 21.03.2019. The universe of the research consists of 395 family physicians who actively work in family health centers. Questionnaire method was used in the research and it was aimed to reach the whole universe. In the study, $75.8 \%$ of the universe (299 people) was reached. To conduct the research, OMÜ Clinical Research Ethics Committee report and necessary permissions were obtained. In the study, significant differences were found between the emotional exhaustion levels of family physicians and the district they work in, the average number of patients looked at per day, professional competence and satisfaction with the institution. In the study, while there were significant differences between the desensitization levels of family physicians and the status of entering TUS and satisfaction with the institution, significant differences were found between low personal achievement levels and professional competence and institution satisfaction. While family physicians working in the central districts experience more emotional exhaustion than those in other districts, family physicians who look at more than 60 patients per day experience more emotional exhaustion than those who look at less patients per day. In addition, family physicians, who do not find themselves professionally competent, experience more emotional exhaustion and lower personal success than those who find themselves professionally sufficient.
\end{abstract}

Keywords: Burnout, Family medicine, Family physicians, Primary care. öz

Çalışma, hekim-hasta ilişkisinde önemli bir faktör olan hekimlerin tükenmişlik düzeylerini ve bu düzeyi etkileyen faktörleri belirlemeyi amaçlamaktadır. Çalışma 21.03.2018 - 21.03.2019 tarihleri arasında Samsun'daki aile sağlığı merkezlerinde uygulanmıştır. Araştırmanın evrenini aile sağlığı merkezlerinde aktif olarak görev yapan 395 aile hekimi oluşturmaktadır. Araştırmada anket yöntemi kullanılmış ve tüm evrene ulaşılması amaçlanmıştır. Çalışmada evrenin \% 75,8'ine (299 kişi) ulaşılmıştır. Araştırmanın yürütülmesi için OMÜ Klinik Araştırmalar Etik Kurulu raporu ve gerekli izinler alınmıştır. Çalışmada aile hekimlerinin duygusal tükenme düzeyleri ile çalıştıkları ilçe, günlük bakılan ortalama hasta sayısı, mesleki yeterlilik ve kurumdan memnuniyetleri arasında anlamlı farklılıklar bulunmuştur. Araştırmada aile hekimlerinin duyarsızlaşma düzeyleri ile Tıpta Uzmanlık Sinavi'ina (TUS) girme durumu ve kurumdan memnuniyet arasında anlamlı farklılıklar bulunurken, düşük kişisel başarı düzeyleri ile mesleki yeterlilik ve kurumdan memnuniyet arasında anlamlı farklılıklar bulunmuştur. Merkez ilçelerde çalışan aile hekimleri diğer ilçelere göre daha fazla duygusal tükenme yaşarken, günde 60'tan fazla hastaya bakan aile hekimleri, daha az hastaya bakanlara göre daha fazla duygusal tükenme yaşamaktadır. Ayrıca kendilerini mesleki olarak yeterli bulmayan aile hekimleri, kendilerini mesleki olarak yeterli bulanlara göre daha fazla duygusal tükenme yaşarlarken, kişisel başarı düzeyleri ise daha düşüktür.

Anahtar Kelimeler: Tükenmişlik, Aile hekimliği, Aile hekimleri, Birinci basamak.

Permission was obtained from the OMU Clinical Research Ethics Committee for the study. This study was produced from the master's thesis of the first author. This study was supported by the Scientific Research Projects (BAP) unit of Ondokuz Mayls University (OMÜ BAP Project No: PYO.SBF.1904.18.007)

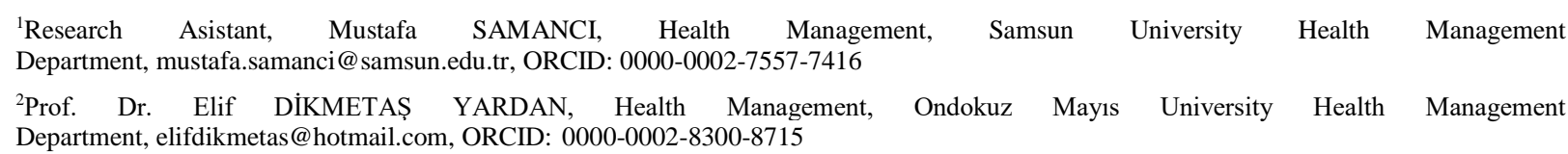




\section{INTRODUCTION}

The relationship of people with their jobs and the difficulties that may arise when these relationships start to go wrong have been a problem of the modern age for many years. The use of the term burnout to name this problem started to appear in the USA (United States of America) in the 1970s, especially among individuals working in jobs that provide services to people. The concept of burnout emerged for the first time in the world, in Green's novel "A Burn-Out Case", published in 1961, when he described how to leave his job and retreat to the African jungle, a mentally tormented and disappointed architect. The study in which the concept of burnout was first explored was carried out in 1975 by Freudenberger, a psychiatrist working in health institutions. ${ }^{1}$ What is Burnout in this study Freudenberger (1975) conducted on health workers? What are the Symptoms? What kind of personalities are more prone to burnout than others? He sought answers to such questions. According to Freudenberger, burnout is the state of feeling of exhaustion experienced due to loss of energy and power after the unmet demands of individuals. ${ }^{2}$ Although there are many definitions of burnout in the literature, the most known and accepted of these definitions is Maslach. ${ }^{3}$ Maslach defines burnout as a very common emotional exhaustion and cynicism problem in individuals dealing with people because of their work. ${ }^{4}$ Burnout is also described as emotional exhaustion, cynicism and decreased effectiveness in the working environment. $^{5}$ Burnout, symptoms and degrees vary from person to person, occurring in many different symptomatic ways and generally begins to occur one year after the individual starts working in the institution. $^{2}$ Burnout still remains a permanent problem among healthcare professionals, although it is a problem that requires sophisticated solutions and is poorly understood yet. ${ }^{6}$ The loss of more than ten thousand patients a year as a result of preventable errors has led to the question of whether the state of burnout among physicians and other professionals working in health institutions will harm the patient. ${ }^{7}$ Low patient satisfaction in primary health care is directly related to burnout syndrome, which occurs with loss of emotional, mental and physical energy. ${ }^{8}$ When an exhausted physician is nervous and impatient, it also reduces productivity and lowers the quality of care. ${ }^{7}$ Again, the burnout of physicians negatively affects patient care and destabilizes the workforce. ${ }^{9}$ Patient care and physician well-being are indicators of quality in healthcare, and the well-being of the physician is a common problem shared by individuals, organizations and society. When physicians feel well, they can perform healthcare services in the best way. However, problems such as dissatisfaction and burnout can negatively affect the well-being of physicians, resulting in poor patient care, low patient satisfaction, and increased health care costs. ${ }^{10}$

Burnout may also be associated with alcohol use of physicians, suicidal ideation, decreased quality of patient care, and worsening patient results. ${ }^{11}$

Burnout syndrome also has quite negative effects on the professionalism and communication skills of physicians. ${ }^{12}$ Furthermore, burnout in physicians is also partly associated with physicians' exposure to working environment factors. Factors such as long working hours and excessive workload can cause burnout among physicians. ${ }^{13,} 14$ Moreover worsening mental and physical health levels of physicians, burnout is another factor affecting the intention to quit from job. ${ }^{15}$ Hoff et al. (2002), it was concluded that $44 \%$ of physicians exposed to burnout aim to quit their jobs within four years. ${ }^{16}$

Burnout in American physicians is high, but generally affects more than $50 \%$ of physicians, and this rate may be even higher among some specialties. ${ }^{6,17}$ Schanafelt et al. (2009), it is stated that almost half of the surgeons living in the United States have at least one burnout symptom. ${ }^{18}$ Again, 
Shanafelt et al. (2012), it was concluded that the prevalence of burnout varies greatly according to their areas of expertise. ${ }^{19}$ It is stated that the risk of burnout is higher especially in family medicine, emergency medicine and neurology branches. ${ }^{9}$ Rassolian et al. (2017), it is stated that family physicians experience burnout by $25 \% .^{20} \mathrm{In}$ Western societies, there are quite serious signs of burnout among family physicians. Many family physicians want to leave their jobs or retire early due to burnout. ${ }^{21}$
Research on burnout is imperative to improve patient care quality, improve physician health, and reduce health care costs. ${ }^{20}$ Especially since burnout in primary care is higher than in other disciplines, very important activities are needed to combat burnout and improve results. ${ }^{22}$

Republic of Turkey, Samsun city center and working in district health centers in the family physician burnout levels and aimed to determine the factors that affect burnout levels.

\section{MATHERİAL AND METHODS}

The questionnaire method was used in the study. Family physicians working in family health centers in Samsun centers and districts are the universe of the research. The research was carried out between 21.03.2018 21.03.2019. The information of the family physician working actively during the study period was obtained from the Samsun Provincial Health Directorate website. There are a total of 395 active family physicians at the time of the survey. Since it was desired to reach the whole population in the study, the sample calculation was not made. The questionnaires were applied face to face to the participants. The study included 299 family physicians and $75.8 \%$ of the universe was reached.

\section{Ethical Aspect of Research}

Necessary permissions were obtained from the Ondokuz Mayıs University Clinical Research Ethics Committee and Samsun Governorship Provincial Health Directorate for conducting the research. Informed consent of each family physician was obtained individually. (OMÜ Clinical Research Ethics Committee Decision No: OMÜ KAEK 2017/375)

This study was produced from the master's thesis titled "Aile Hekimlerinin Öz yeterlilik Algılarının Tükenmişlikleri Üzerindeki Etkisi”. (Yök Tez No: 560399)

This study was supported by the Scientific Research Project (BAP) unit of Ondokuz
Mayıs University. OMÜ BAP Proje No: PYO.SBF.1904.18.007

\section{Data Collection Tools}

The questionnaire used to collect data in the study consists of two parts. While demographic information included in the first section, "Maslach Burnout Inventory" used in the second section.

Maslach Burnout Inventory: Maslach Burnout Inventory is the most common measurement tool of burnout. The scale, which was developed by Maslach and Jackson (1981) and whose validity and reliability study was conducted by Ergin (1992), emerged as a 7-point likert type and turned into a 5-point likert type when translated into Turkish. Answers to scale expressions consisting of 22 expressions are between " 1 " (never) and " 5 " (always). 9 of 22 expressions in the scale belong to emotional exhaustion, 5 to be depersonalization and 8 to low personal accomplishment. ${ }^{23}$ High emotional exhaustion and depersonalization scores mean high burnout, while low personal achievement scores mean high burnout. Emotional exhaustion and depersonalization consists of negative expressions, and personal success consists of positive expressions. Therefore, reverse coding was made for the statements in the personal success sub-dimension. As a result, the general burnout score was also calculated. The high personal success score after these transactions also means high burnout. After 
these procedures, the "personal success" subscale can be interpreted as the "low personal success feeling" subscale.

Since the kurtosis and skewness values of the data in the study are between +1.5 and 1.5 , it is accepted that the data show a normal distribution. Parametric tests were used in the study as the data showed a normal distribution. Independent Sample T-Test was used when comparing two independent groups and One Way Anova test was used when more than two independent groups were compared. In the comparison of more than two independent groups, in cases where there is a difference between the groups, Tukey-HSD test, which is a Post Hoc analysis, was used to determine which group the difference belongs to.

\section{Limitatiton of Research}

The most important limitation of the study is that it covers only family physicians working in family health centers in Samsun. In addition, another limitation is the difficulties in accessing family physicians due to the inclusion of family physicians working in the villages.

\section{RESULTS AND DISCUSSION}

The socio-demographic characteristics of the participants are shown in Table 1. Accordingly, 66\% (199 people) of the participants are men, while $52.2 \%$ are over 47 years old. When the marital status is examined, the majority of the participants $(89 \%)$ are married. Again, those who are less than 12 years in the year in which family physicians participated in the study worked as family physicians constitute the majority with $67.9 \%$. While $56.2 \%$ of the participants work in the central district, $51.2 \%$ of the registered patient population is 3500 and below. While the average number of patients looked after 60 and over is $57.5 \%$ (172 people), the rate of those who love the institution they work is $68.6 \%$ (205 people). While $89 \%$ of the family physicians participating in the research find themselves professionally adequate, $51.8 \%$ feel themselves burnout professionally.

Table 1. Sociodemographic Characteristics of Family Physicians

\begin{tabular}{|c|c|c|c|}
\hline \multicolumn{2}{|l|}{ Independent Variable } & \multirow{2}{*}{$\begin{array}{r}\text { Number (n) } \\
100\end{array}$} & \multirow{2}{*}{$\begin{array}{r}\begin{array}{r}\text { Percentage } \\
(\%)\end{array} \\
33.4\end{array}$} \\
\hline Gender & Women & & \\
\hline & Man & 199 & 66.6 \\
\hline \multirow[t]{2}{*}{ Age } & $\leq 47$ & 143 & 47.8 \\
\hline & $>47$ & 156 & 52.2 \\
\hline \multirow{2}{*}{ Marital status } & Single & 33 & 11.0 \\
\hline & Married & 266 & 89.0 \\
\hline \multirow{2}{*}{$\begin{array}{l}\text { How many years worked as a } \\
\text { family physcian }\end{array}$} & $\leq 12$ & 203 & 67.9 \\
\hline & $>12$ & 96 & 32.1 \\
\hline \multirow[t]{2}{*}{ The district where you work } & Central districts & 168 & 56.2 \\
\hline & Other districts & 131 & 43.8 \\
\hline \multirow[t]{2}{*}{ Registered patient population } & 3500 and below & 153 & 51.2 \\
\hline & 3501 and above & 146 & 48.8 \\
\hline \multirow{2}{*}{$\begin{array}{l}\text { Number of patients examined per } \\
\text { day }\end{array}$} & 59 and below & 127 & 42.5 \\
\hline & 60 and above & 172 & 57.5 \\
\hline \multirow{3}{*}{$\begin{array}{l}\text { Do you like the institution you } \\
\text { work for? }\end{array}$} & Yes & 205 & 68.6 \\
\hline & Partially & 84 & 28.1 \\
\hline & No & 10 & 3.3 \\
\hline \multirow{2}{*}{$\begin{array}{l}\text { Do you find yourself professionally } \\
\text { competent? }\end{array}$} & Yes & 266 & 89.0 \\
\hline & No & 33 & 11.0 \\
\hline \multirow{2}{*}{$\begin{array}{l}\text { Do you feel burnout } \\
\text { professionally? }\end{array}$} & Yes & 155 & 51.8 \\
\hline & No & 144 & 48.2 \\
\hline \multirow[t]{2}{*}{ Your working status? } & General practitioner & 273 & 91.3 \\
\hline & Specialist physician & 26 & 8.7 \\
\hline \multirow{2}{*}{$\begin{array}{l}\text { Entrance to the medical specialty } \\
\text { exam (TUS) after starting to work } \\
\text { as a family doctor }\end{array}$} & Yes & 46 & 15.4 \\
\hline & No & 253 & 84.6 \\
\hline
\end{tabular}


When Table 2, which shows the burnout averages of the family physicians participating in the study, is examined, the depersonalization (avg: $5.23 \pm 3.40$ ) levels of emotional exhaustion (avg: $15.60 \pm 7.86$ ) and low personal sense of accomplishment (avg: $11.01 \pm 3.53$ ) levels seem to be at the normal burnout level.

Table 2. Average of Burnout Levels of Family Physicians

\begin{tabular}{lccrrr}
\hline $\begin{array}{l}\text { Independent } \\
\text { variable }\end{array}$ & $\mathbf{n}$ & Average & $\begin{array}{l}\text { Standard } \\
\text { deviation }\end{array}$ & Minimum & Maximum \\
\hline $\begin{array}{l}\text { Emotional } \\
\text { exhaustion }\end{array}$ & 299 & 15.60 & 7.86 & 0 & 32 \\
\hline Depersonalization & 299 & 5.23 & 3.40 & 0 & 15 \\
\hline $\begin{array}{l}\text { Low personal } \\
\text { Achievement }\end{array}$ & 299 & 11.01 & 3.53 & 2 & 22 \\
\hline General burnout & 299 & 31.83 & 12.08 & 9 & 63 \\
\hline
\end{tabular}

The distribution of burnout scores of 1 significantly according to gender, age, family physicians according to marital status, year worked as a family sociodemographic variables is shown in Table 3. According to Table 3, burnout levels of family physicians do not differ doctor, registered average patient population and employment status.

Table 3. Distribution of Burnout Scores of Family Physicians According to Sociodemographic Variables

\begin{tabular}{|c|c|c|c|c|}
\hline Independent variable & $\begin{array}{r}\text { Emotional exhaustion } \\
(\text { Avg } \pm \text { SD) }\end{array}$ & $\begin{array}{r}\text { Depersonalization } \\
(\text { Avg } \pm \text { SD })\end{array}$ & $\begin{array}{r}\text { Low personal } \\
\text { Achievement } \\
(\text { Avg } \pm \text { SD })\end{array}$ & $\begin{array}{r}\text { General burnout } \\
(\text { Avg } \pm \text { SD) }\end{array}$ \\
\hline \multicolumn{5}{|l|}{ Gender *t } \\
\hline Women & $15.85 \pm 7.52$ & $5.19 \pm 3.48$ & $10.67 \pm 3.41$ & $31.71 \pm 12.02$ \\
\hline Man & $15.46 \pm 8.04$ & $5.25 \pm 3.38$ & $11.18 \pm 3.58$ & $31.90 \pm 12.13$ \\
\hline $\mathrm{p}$ & $=0.69$ & $=0.88$ & $=0.23$ & $=0.89$ \\
\hline $\mathrm{t}$ & 0.39 & -0.14 & -1.19 & -0.13 \\
\hline \multicolumn{5}{|l|}{ Age*t } \\
\hline$\leq 47$ & $15.90 \pm 8.18$ & $5.30 \pm 3.31$ & $10.79 \pm 3.49$ & $32.00 \pm 12.17$ \\
\hline$>47$ & $15.31 \pm 7.58$ & $5.16 \pm 3.50$ & $11.21 \pm 3.57$ & $31.69 \pm 12.03$ \\
\hline $\mathrm{p}$ & $=0.51$ & $=0.73$ & $=0.31$ & $=0.82$ \\
\hline $\mathrm{t}$ & 0.64 & 0.33 & -1.01 & 0.22 \\
\hline \multicolumn{5}{|l|}{ Marital status *t } \\
\hline Single & $14.69 \pm 9.09$ & $4.87 \pm 3.67$ & $10.30 \pm 3.23$ & $29.87 \pm 13.03$ \\
\hline Married & $15.70 \pm 7.71$ & $5.27 \pm 3.38$ & $11.10 \pm 3.56$ & $32.08 \pm 11.96$ \\
\hline $\mathrm{P}$ & $=0.48$ & $=0.53$ & $=0.22$ & $=0.32$ \\
\hline $\mathrm{T}$ & -0.69 & -0.62 & -1.22 & -0.98 \\
\hline \multicolumn{5}{|c|}{ How many years worked as a family physcian *t } \\
\hline$\leq 12$ & $15.62 \pm 8.11$ & $5.14 \pm 3.43$ & $10.96 \pm 3.53$ & $31.72 \pm 12.43$ \\
\hline$>12$ & $15.54 \pm 7.36$ & $5.41 \pm 3.36$ & $11.11 \pm 3.55$ & $32.07 \pm 11.36$ \\
\hline $\mathrm{p}$ & $=0.93$ & $=0.51$ & $=0.73$ & $=0.81$ \\
\hline $\mathrm{t}$ & 0.08 & -0.64 & -0.34 & -0.22 \\
\hline \multicolumn{5}{|c|}{ The district where you work $* t$} \\
\hline Central districts & $16.72 \pm 7.86$ & $5.49 \pm 3.27$ & $11.11 \pm 3.59$ & $33.34 \pm 11.98$ \\
\hline Other districts & $14.14 \pm 7.65$ & $4.89 \pm 3.55$ & $10.87 \pm 3.46$ & $29.91 \pm 11.97$ \\
\hline $\mathrm{p}$ & $=0.005$ & $=0.131$ & $=0.559$ & $=0.015$ \\
\hline $\mathrm{t}$ & 2.84 & 1.51 & 0.58 & 2.45 \\
\hline \multicolumn{5}{|c|}{ Registered patient population *t } \\
\hline 3500 and below & $15.18 \pm 7.92$ & $5.39 \pm 3.63$ & $11.30 \pm 3.66$ & $31.88 \pm 12.57$ \\
\hline 3501 and above & $16.02 \pm 7.80$ & $5.06 \pm 3.15$ & $10.71 \pm 3.37$ & $31.79 \pm 11.58$ \\
\hline $\mathrm{p}$ & $=0.36$ & $=0.40$ & $=0.15$ & $=0.95$ \\
\hline $\mathrm{t}$ & -0.91 & 0.83 & 1.44 & 0.06 \\
\hline \multicolumn{5}{|c|}{ Number of patients examined per day *t } \\
\hline 59 and below & $14.17 \pm 8.10$ & $5.18 \pm 3.47$ & $11.04 \pm 3.62$ & $30.40 \pm 12.65$ \\
\hline 60 and above & $16.64 \pm 7.54$ & $5.26 \pm 3.36$ & $10.98 \pm 3.47$ & $32.89 \pm 11.56$ \\
\hline$p$ & $=0.007$ & $=0.856$ & $=0.887$ & $=0.079$ \\
\hline $\mathrm{t}$ & -2.71 & -0.18 & 0.14 & -1.76 \\
\hline
\end{tabular}




\begin{tabular}{|c|c|c|c|c|}
\hline $\begin{array}{l}\text { GÜSBD 2021; 10(4): } 705 \text { - } 713 \\
\text { GUJHS 2021; 10(4): } 705-713\end{array}$ & \multicolumn{3}{|c|}{$\begin{array}{l}\text { Gümüşhane Üniversitesi Sağlık Bilimleri Dergisi } \\
\text { Gümüşhane University Journal of Health Sciences }\end{array}$} & \multirow[t]{2}{*}{$\begin{array}{r}\text { Araştırma Mal } \\
\text { Original A } \\
\end{array}$} \\
\hline ble 4 (Continue). & & & & \\
\hline Independent variable & $\begin{array}{r}\text { Emotional exhaustion } \\
(\text { Avg } \pm \text { SD) }\end{array}$ & $\begin{array}{r}\text { Depersonalization } \\
(\text { Avg } \pm \text { SD) }\end{array}$ & $\begin{array}{r}\text { Low personal } \\
\text { Achievement } \\
(\text { Avg } \pm \text { SD) }\end{array}$ & $\begin{array}{r}\text { General burnout } \\
(\text { Avg } \pm \text { SD })\end{array}$ \\
\hline \multicolumn{5}{|c|}{ Do you find yourself professionally competent? $*$ t } \\
\hline Yes & $15.20 \pm 7.90$ & $5.13 \pm 3.41$ & $10.76 \pm 3.48$ & $31.10 \pm 12.02$ \\
\hline No & $18.75 \pm 6.83$ & $6.00 \pm 3.28$ & $13.03 \pm 3.33$ & $37.78 \pm 10.99$ \\
\hline $\mathrm{p}$ & $=0.014$ & $=0.170$ & $=0.001$ & $=0.003$ \\
\hline $\mathrm{t}$ & -2.46 & -1.37 & -3.54 & -3.04 \\
\hline \multicolumn{5}{|l|}{ Working status? $*$ t } \\
\hline General practitioner & $15.57 \pm 8.04$ & $5.26 \pm 3.41$ & $11.08 \pm 3.54$ & $31.91 \pm 12.27$ \\
\hline Specialist physician & $15.80 \pm 5.79$ & $4.92 \pm 3.39$ & $10.26 \pm 3.38$ & $31.00 \pm 10.00$ \\
\hline $\mathrm{p}$ & $=0.88$ & $=0.63$ & $=0.26$ & $=0.71$ \\
\hline $\mathrm{t}$ & -0.14 & 0.48 & 1.12 & 0.37 \\
\hline \multicolumn{5}{|c|}{ Entrance to the medical specialty exam (TUS) after starting to work as a family physician *t } \\
\hline Yes & $16.26 \pm 6.69$ & $6.30 \pm 3.35$ & $11.36 \pm 3.24$ & $33.93 \pm 11.12$ \\
\hline No & $15.47 \pm 8.06$ & $5.03 \pm 3.39$ & $10.94 \pm 3.58$ & $31.45 \pm 12.22$ \\
\hline $\mathrm{p}$ & $=0.534$ & $=0.020$ & $=0.458$ & $=0.201$ \\
\hline $\mathrm{t}$ & 0.62 & 2.33 & 0.74 & 1.28 \\
\hline \multicolumn{5}{|c|}{ Do you like the institution you work for? $*$ a } \\
\hline Yes & $13.28 \pm 7.12$ & $4.61 \pm 3.07$ & $10.50 \pm 3.57$ & $28.40 \pm 10.91$ \\
\hline Partially & $20.07 \pm 6.49$ & $6.21 \pm 3.46$ & $11.98 \pm 3.07$ & $38.27 \pm 10.17$ \\
\hline No & $25.40 \pm 9.64$ & $9.50 \pm 4.74$ & $13.20 \pm 4.07$ & $48.10 \pm 15.13$ \\
\hline $\mathrm{p}$ & $=0.001$ & $=0.001$ & $=0.001$ & $=0.001$ \\
\hline $\mathrm{F}$ & 37.64 & 16.10 & 7.52 & 35.12 \\
\hline
\end{tabular}

Emotional exhaustion levels of family physicians show significant differences according to the district they work in $(\mathrm{t}: 2.84$; $\mathrm{p}<0.05)$, the average number of patients they look at in a day $(\mathrm{t}:-2.71 ; \mathrm{p}<0.05)$ finding themselves professionally competent $(\mathrm{t}$ : 2.46; $\mathrm{p}<0.05)$ and their satisfaction with the institution they work $(\mathrm{F}: 37.64 ; \mathrm{p}<0.05)$. The depersonalization levels of family physicians show significant differences according to entering TUS ( $t: 2.33 ; p<0.05$ ) and satisfaction with the institution studied (F: $16.10 ; p<0.05$ ). Low personal success levels of family physicians differ according to the variables of finding themselves competent enough ( $\mathrm{t}:-3.54 ; \mathrm{p}<0.05)$ and satisfaction with the institution they work for (F: 7.52; $\mathrm{p}<0.05)$. General burnout levels of family physicians, the district they work in (t: 2.45; $\mathrm{p}<0.05$ ), finding themselves professionally competent (t: 3.04; $\mathrm{p}<0.05)$ and being satisfied with the institution they work for (F: 35.12; $\mathrm{p}<0.05)$ varies significantly according to variables.

In the study, the relationship between burnout, which is one of the biggest problems among family physicians, and some socio-demographic variables was examined.
In the study, no significant differences were found in the dimensions of emotional exhaustion, depersonalization and low personal accomplishment in terms of age, gender, marital status, year of work as a family physician, registered patient population, and employment status ( $\mathrm{p}>$ 0.05).

The relationship between individual demographic characteristics and burnout has been studied extensively so far. According to Maslach et al., The variable most associated with burnout among all demographic variables is the age variable. According to Maslach et al., Employees belonging to age groups under the age of 30 or 40 experience more burnout than those over the age of 30 or 40 . Although there are some claims that burnout is mostly a women's experience, the gender variable is not a strong predictor of burnout. ${ }^{1}$ In the study by Creager, Coutinho and Peterson (2019), it was concluded that burnout decreased significantly in physicians after the age of 60 and no relation was found between gender and burnout. ${ }^{11}$ Weidner et al. (2018), according to the results of a study conducted on family physicians, the burnout level of female family physicians is higher than that of male family physicians. ${ }^{24}$ 
Emotional exhaustion and low sense of personal accomplishment perceptions of gender, age and studies in which there is no significant difference according to marital status are included in the literature. ${ }^{23,24-32}$ It is thought that the reason of the different results in the studies may be related to the factors such as the samples of the studies, the countries in which they are conducted, the level of welfare of the participants, the differences in the social culture and values.

In the study, it was determined that the emotional exhaustion levels of physicians differ significantly according to the district they work in and the average number of patients they care for daily. Sünter et al. (2006), while there is no significant difference between the burnout levels of physicians according to their district, Şerik et al. (2016), on the other hand, a significant difference was found in the burnout levels of those who do not work in the central district compared to those who work in the central districts. $^{30,} 33$ Weidner et al. (2018), in a study conducted on family physicians, there were no significant differences between the average number of patients per day and burnout, while Şerik et al. (2016), it was concluded that with the increase in the number of daily patients, the personal success score also increased. ${ }^{24,33}$ The reason for these differences in the results is thought to be related to the periods in which the studies were conducted and the differences between the countries.

In this study, it was concluded that emotional exhaustion, depersonalization, low sense of personal accomplishment and general burnout scores differ significantly according to satisfaction with the institution studied. Baykan et al. (2014), in a study on family physicians, a significant difference was found in the emotional exhaustion, depersonalization and total burnout scores of the family physicians who were not satisfied with the work environment compared to the family physicians who were satisfied with the work environment. ${ }^{32}$

According to whether the family physicians who participated in the study found themselves professionally adequate, there were no significant differences between the depersonalization scores, but significant differences were found between emotional exhaustion and low personal accomplishment scores. Elbi et al. (2014), in a study on healthcare professionals in family medicine, a significant relationship was found between finding himself professionally successful and only the personal success variable. ${ }^{34}$

According to the Medscape report as a result of researches conducted in the USA in $2018,42 \%$ of 15,000 US physicians were found to be burnout. It is stated that the period in which burnout is experienced the most is between the ages of 45-54. According to the study, the most common burnout area after intensive care physicians and neurologists is family medicine. According to this report, the most important factor causing physicians to experience burnout is dealing with paperwork in the working environment. ${ }^{35}$ According to the report published by Medscape in 2020, among the most exposed specialties to burnout, family medicine dropped to 5 th place and it was concluded that women experienced more burnout than men. The most important factor causing burnout is stated in this report, as in the 2018 report, is that doctors deal with paperwork. ${ }^{36}$

\section{CONCLUSION AND RECOMMENDATION}

According to the results of the study, family physicians serving 60 or more patients per day experience more emotional exhaustion than family physicians serving less patients. While family physicians who do not find themselves professionally sufficient experience more emotional exhaustion than family physicians who consider themselves professionally adequate, family physicians who are not satisfied with the institution they work with experience more emotional exhaustion than family physicians who are satisfied with the institution they work. In order to reduce the 
burnout levels of physicians, the average number of patients served per day should be reduced, public information spots should be prepared for patients, trainings and seminars to increase the professional competence levels of physicians should be made more frequent, and necessary arrangements should be made for physicians to love the environment and institution they work in.

One of the methods that can be applied to reduce burnout in family medicine is the Balint Groups method. Balint groups help healthcare professionals improve their coping with psychosocial stress factors in a supportive and accepted group setting. ${ }^{37}$ It is stated that the Balint group method improves communication skills and makes physicians more sensitive to the psychological processes of the patient. ${ }^{38}$ Balint groups are very active worldwide. ${ }^{39}$ It is a commonly used educational activity in family medicine in the USA, and in Europe, many Balint groups are composed of family physician specialists. ${ }^{40}$ The aim of the Balint groups is to improve the physicians' ability to manage their patients. Therefore, Balint groups can provide opportunities for family physicians and offer them strategies to manage their working lives. ${ }^{21}$ The results of the research conducted by Rabinowitz, Kushin and Ribak
(1996) on health workers showed that after the Balint group, there was a significant increase in the awareness and abilities of health workers and a significant decrease in their emotional exhaustion. ${ }^{37}$

In addition, as stated in the literature and the Medscape 2018 and 2020 reports, the most important reason for family physicians to experience burnout is their paperwork. In order to improve this situation, it is recommended to employ a health manager in every family medicine. Providing this situation will eliminate the most important factor that causes family physicians to experience burnout. This is also very important for the improvement of health systems, as there are contributions such as reducing costs and hospitalization rates among the benefits of family physicians. More studies are needed to determine the factors affecting burnout levels of family physicians providing preventive healthcare services. The development of the family medicine system depends on the physiological and psychological well-being of family physicians. Therefore, studies on the burnout of family physicians should be carried out in the future and the results should be constantly monitored by comparative analysis. 


\section{REFERENCES}

1. Maslach, C, Schaufeli, W. B and Leiter, M.P. (2001) "Job Burnout". Annual Reviews. Psychol, 52, 397-422.

2. Freudenberger, H.J. (1975). "Staff Burn- Out". Journal of Social Issues, 30 (1), 159-165

3. Bauernhofer, K, Bassa, D. Canazei, M. et al. (2018). "Subtypes in Clinical Burnout Patients Enrolled in An Employee Rehabilitation Program: Differences in Burnout Profiles, Depression, and Recovery/Resources-Stress Balance." BMC Psychiatry, 18 (10). https://doi.org/10.1186/s12888-018-1589-y

4. Maslach, C. and Jackson, S.E. (1981). "The Measurement of Experienced Burnout". Journal of Occupational Behaviour, 2, 99-113.

5. Jager, A.J, Tutty, M.A. and Kao, A.C. (2016). "Association Between Physician Burnout and Identification With Medicine as a Calling". Mayo Clinic Proceedings. 2016, 1-8.

6. Shanafelt, T.D, Hasan, O, Dyrbye, L.N. et al. (2015). "Changes in Burnout and Satisfaction With Work-Life Balance in Physicians and the General US Working Population Between 2011 and 2014". Mayo Clinic Proceedings, 90 (12), 1600-1613.

7. Yates, W.S. (2020). "Physician Stress and Burnout". The American Journal of Medicine, 133 (2), 160-164

8. Mundt, M.P. and Zakletskaia, L.I. (2019). "Professional Communication Networks and Job Satisfaction in Primary Care Clinics". Annals of Family Medicine, 17 (5), 428-435.

9. Shanafelt, T, Goh, J. and Sinsky, C. (2017). "The Business Case for Investing in Physician Well-being". JAMA Internal Medicine, 177 (12), 1826-1832.

10. Thomas, L.R, Ripp, J.A. and West, C.P. (2018). "Charter on Physician Well-being”. JAMA, 319 (15), 1541-1542.

11. Creager, J, Coutinho, A.J and Peterson, L.E. (2019). "Associations Between Burnout and Practice Organization in Family Physicians". Annals of Family Medicine, 17 (6), 502-509.

12. Dyrbye, L.N, Massie, F.S, Eacker, A. et al. (2010) "Relationship Between Burnout and Professional Conduct and Attitudes Among US Medical Students". JAMA, 304 (11) 1173-1180.

13. Martin, S. (2002). "More Hours, More Tired, More To Do: Results From The CMA's 2002 Physician Resource Questionnaire". Canadian Medical Association Journal, 167 (5), 521-522.

14. Virtanen, P, Oksanen, T, Kvimaki, M, Virtanen, M, Pentti, J and Vahtera, J. (2008). "Work Stress and Health in Primary Health Care Physicians and Hospital Physicians". Occupational and Environmental Medicine, 65, 364-366.

15. Williams, E.S, Konrad, T.R, Scheckler, W.E. et al. (2010) "Understanding Physicians' Intentions To Withdraw from Practice: The Role of Job Satisfaction, Job Stress, Mental and Physical Health". Health Care Management Review, 35 (2), 105-115.

16. Hoff, T, Whitcomb, W.F. and Nelson, J.R. (2002). "Thriving and Surviving in a New Medical Career: The Case of Hospitalist Physicians". Journal of Health and Social Behavior, 43 (1), 72-91.

17. Doolittle, B.R. (2016). "Are We the Walking Dead? Burnout as Zombie Apocalypse". Annals of Family Medicine, 14, 578-580.

18. Shanafelt, T.D, Balch, C.M, Bechamps, G.J. et al. (2009). "Burnout and Career Satisfaction Among American Surgeons". Annals of Surgery, 250, 107-115

19. Shanafelt, T.D, Boone, S, Tan, L. et al. (2012). "Burnout and Satisfaction With Work-Life Balance among US Physicians Relative to the General US Population". Archives of Internal Medicine, 172 (18), 1377-1385.

20. Rassolian, M, Peterson, L.E, Fang, B. et al. (2017). "Workplace Factors Associated With Burnout of Family Physicians". JAMA Internal Medicine, 177 (7), 1391.

21. Kjeldmand, D. and Holmström, I. (2008). "Balint Groups as a Means to Increase Job Satisfaction and Prevent Burnout among General Practitioners". Annals of Family Medicine, 6, 138-145.

22. Shanafelt, T.D, Sinsky, C, Dyrbye, L.N, Trockel, M. and West, C.P. (2019). "Burnout Among Physicians Compared With İndividuals With A Professional or Doctoral Degree in A Field Outside of Medicine". Mayo Clinic Proceedings, 94 (3), 549. 551.
23. Dikmetas, E, Top, M. ve Ergin, G. (2011). “Asistan Hekimlerin Tükenmişlik ve Mobbing Düzeylerinin İncelenmesi”. Türk Psikiyatri Dergisi, 22 (3), 137-149.

24. Weidner, A.K.H, Phillips, R.L, Fang, B. and Peterson, L.E. (2018). "Burnout and Scope of Practice in New Family Physicians". Annals of Family Medicine, 16, 200-205.

25. Soler, J.K, Yaman, H. and Esteva, M. (2008). "Burnout in European Family Doctors: The EGPRN Study". Family Practice, 25, 245-65.

26. Sayıl, I, Haran, S, Ölmez, Ș. ve Özgüven, D.H. (1997). “Ankara Üniversitesi Hastanelerinde Çalıșan Doktor ve Hemșirelerin Tükenmişlik Düzeyleri”. Kriz Dergisi, 5 (2), 71-77.

27. Güdük, M, Erol, S, Yağcıbulut, Ö, Uğur, Z, Özvarıs, S.B. ve Aslan, D. (2005). "Ankara'da Bir Tip Fakültesinde Okuyan Son Sınıf Öğrencilerde Tükenmişlik Sendromu”. Sürekli Tıp Eğitimi Dergisi, 14 (8), 169-173.

28. Kurçer, M.A. (2005). "Harran Üniversitesi Tıp Fakültesi Hemșirelerinin İs Doyumu ve Tükenmişlik Düzeyleri”. Harran Universitesi Tıp Fakültesi Dergisi, 2 (3), 10-15.

29. Taycan, O, Kutlu, L, Çimen, S. ve Aydın, N. (2006). "Bir Üniversite Hastanesinde Calışan Hemșirelerde Depresyon ve Tükenmişlik Düzeyinin Sosyodemografik Özelliklerle İlişkisi”. Anadolu Psikiyatri Dergisi, 7, 100-108.

30. Sünter, A.T, Canbaz, S, Dabak, Ş, Pekşen, Y. ve Öz, H. (2006). "Pratisyen Hekimlerde Tükenmişlik, İșe Bağlı Gerginlik ve İş Doyumu Düzeyleri”. Genel Tıp Dergisi, 16 (1), 9-14.

31. Helvacı, I. ve Turhan, M. (2013). "Tükenmişlik Düzeylerinin Incelenmesi: Silifke'de Görev Yapan Sağlık Calıșanlar Üzerinde Bir Araştırma". İşletme ve İktisat Çalışmaları Dergisi, 1 (4), 58-68.

32. Baykan, Z, Cetinkaya, F, Naçar, M, Kaya, A. ve Issıldak, N.Ü. (2014). "Aile Hekimlerinin Tükenmişlik Durumları ve İlişkili Faktörler”. Türkiye Aile Hekimliği Dergisi, 18 (3), 122-133.

33. Şerik, B, Erdoğan, N, Ekerbiçer, Ç.H. et al. (2016). "Sakarya'da Aile Sağlığı Merkezlerinde Calıșan Aile Hekimlerinin Tükenmișlik Düzeyleri ve İlișkili Faktörler", Sakarya Tıp Dergisi, (6) 2, 60-66

34. Elbi, H, Balcı, G.U, Nazik, F, Korkmaz, H. ve Öngel, K (2014). "Afyonkarahisar İlinde Aile Hekimliği Sistemindeki Sağlık Çalışanlarının Tükenmişlik Düzeyleri”. Smyrna Tıp Dergisi, 36-40.

35. Medscape. (2018). "Medscape National Physician Burnout and Depression Report 2018”. https://www.medscape.com/slide show/2018-lifestyle-burnout-depression-6009235\#20 (cited 2020 May 3).

36. Medscape. (2020). "Medscape National Physician Burnout and Suicide Report 2020: The Generational Divide". https://www. medscape.com/slideshow/2020-lifestyle-burnout-6012460\#14 (cited 2020 May 3)

37. Rabinowitz, S, Kushnir, T. and Ribak, J. (1996). "Preventing Burnout Increasing Professional Self Efficacy in Primary Care Nurses in A Balint Group". AAOHN Journal, 44 (1), 28-32.

38. Samuel, O. (1989). "How Doctors Learn in a Balint Group". Family Practice, 6 (2), 108-113.

39. Salinsky, J. (2002). "The Balint Movement Worldwide: Present State and Future Outlook: A Brief History of Balint Around The World". American Journal of Psychoanalysis, 62 (4), $327-$ 335 .

40. Johnson, A.H. (2001). "The Balint Movement in America". Family Medicine, 33 (3), 174-177. 